\title{
INFLUENCE OF HISTAMINE RELEASING AGENTS ON GASTRIC ACID SECRETION OF ISOLATED BULLFROG GASTRIC MUCOSA
}

\author{
Yoshiaki GOTO, Hiroshi Y.WATANABE and Kazuo WATANABE \\ Department of Pharmacometrics, Research Institute for Wakan-yaku, \\ Toyama University, Gofuku 3190, Toyama 930, Japan
}

Accepted July 9, 1976

\begin{abstract}
The influence of histamine releasing agents on gastric acid secretion was studied in isolated bullfrog gastric mucosa preparations. Maximum acid secretory responses in our preparations were obtained by stimulation with tetragastrin $\left(5 \times 10^{-7}\right.$ $\mathrm{g} \cdot \mathrm{ml})$, histamine $\left(1 \times 10^{-5} \mathrm{~g} \cdot \mathrm{ml}\right)$ and bethanechol $\left(1 \times 10^{-6} \mathrm{~g} / \mathrm{ml}\right)$. Compound $48 / 80$ $\left(1 \times 10^{-4} \mathrm{~g} / \mathrm{ml}\right)$ showed a transient stimulatory action which was followed by a gradual depression of basal acid secretion. The stimulatory phase of compound $48 / 80$ was completely antagonized by burimamide $\left(1 \times 10^{-5} \mathrm{~g} / \mathrm{ml}\right)$, a histamine $\mathrm{H}_{2}$-receptor antagonist. In gastric mucosa preincubated with compound 48/80, the secretagogue action of tetragastrin or bethancehol was not exerted, although this preparation continued to respond to histamine. The effects of Triton X-100, decylamine and polymixin $\mathrm{B}$ werc quite similar to those of compound 48,80 . After pretreatment with compound 48,80 , the gastric mucosa preparation became refractory to the stimulatory action of compound $48: 80$ or Triton X-100. It is thus suggested that endogenous histamine may play an important role in the sccretagogue action of tetragastrin and bethanechol.
\end{abstract}

The accumulation of knowledge relating to the role of endogenous histamine in gastric acid secretion (1-5) has been accelerated by the development of histochemical methods of detecting tissue histamine (6). The functional role of gastric histamine is, however, not fully known as it is difficult to study simultaneously the dynamic aspect of histamine movement in the tissue and the change in the gastric acid secretion response. Thus, study of the effect of histamine liberators on gastric acid secretion in isolated gastric mucosa is deemed worthy.

Although there are reports concerning the effect of histamine liberators on gastric acid secretion (7-8), most deal with the complex influence of these agents on gastric functions including systemic and peripheral effects. The effects of histamine liberators on isolated gastric mucosa have been reported (9), but these data appeared before development of the specific histamine $\mathrm{H}_{2}$-receptor antagonist.

The present communication describes the effects of some histamine liberators and a histamine $\mathrm{H}_{2}$-receptor antagonist on the isolated frog gastric mucosa preparation.

\section{MATERIALS AND METHODS}

The isolated bulffrog gastric mucosa preparation

The isolated frog stomach preparation was made following the procedure described by Davidson et al (10) with some modification (11-12). A bullfrog (Rana catesbeiana) was 
decapitated and pithed. The gastric mucosa of the isolated stomach was immediately separated from the muscular layer and was mounted between the lucite chambers cach with a volume of $5 \mathrm{ml}$, containing the following solution: (a) serosal side- $\mathrm{NaCl} 102.7 \mathrm{mM}$, $\mathrm{CaCl}_{2} 0.85 \mathrm{mM}, \mathrm{KCl} 1.0 \mathrm{mM}, \mathrm{NaHCO}_{3} 2.4 \mathrm{mM}$, glucose $11.1 \mathrm{mM}$, (b) mucosal side- $\mathrm{NaCl}$ $105.1 \mathrm{mM}, \mathrm{CaCl}_{2} 0.85 \mathrm{mM}, \mathrm{KCl} 1.0 \mathrm{mM}$, glucose $11.1 \mathrm{mM}$. The rate of acid output was measured by titration with $\mathrm{N} / 500 \mathrm{NaOH}$ to $\mathrm{pH} 6$ using an automatic titrator with a recorder (Toa Electronics Ltd., HS-2A and EPR-3T). The transmucosal potential difference (P.D.) was measured by a pair of calomel electrodes electrically connected via agar- $\mathrm{KCl}$ bridges. The serosal side solution was gassed with the mixture of $95 \% \mathrm{O}_{2}-5 \% \mathrm{CO}_{2}$, and the mucosal side solution was bubbled with $100 \% \mathrm{O}_{2}$. The experiments were carried out at room temperature $\left(15-25^{\circ} \mathrm{C}\right)$.

\section{Histamine assay}

Histamine content in gastric mucosa was determined by the method of Shore et al (13). The isolated stomach was incubated with histamine releasing agents for $30 \mathrm{~min}$ and homogenated for the histamine extraction. The histamine was fluorometrically assayed with a Farrand spectrofluorometer (Mark I). The released histamine in the serosal solution was also assayed according to Rangachari’s method (14-15).

\section{Materials}

The test drugs were dissolved in Ringer's solution and added to the serosal side chamber. The concentrations of the test drugs in this experiment did not affect the $\mathrm{pH}$ of the Ringer solution on the serosal side. The tested concentrations of the drugs were expressed in $\mathrm{g} / \mathrm{ml}$ in terms of the salt. The drugs used were as follows : compound 48/80 (Sigma, U.S.A.), Triton $\mathrm{X}-100$ and histamine $2 \mathrm{HCl}$ (Wako Pure Chem., Japan), burimamide (Smith, Kline and French Laboratories, Fngland, kindly provided by Dr. J.W. Black), tetragastrin (Nissui, Japan) and bethanechol chloride (Yoshitomi, Japan).

\section{RESULTS}

Effect of histamine liberators on spontaneous secretion

Isolated bullfrog gastric mucosa secreted acid spontaneously at a rate of about 380 $\mathrm{m} / \mathrm{eq} . \mathrm{H}^{+} / 4 \mathrm{~cm}^{2 / 1} / 10 \mathrm{~min}$. The polymer amine, compound $48 / 80$ showed a transient stimulatory action followed by a gradual depression of basal acid secretion in the concentration of $1 \times 10^{-4} \mathrm{~g} / \mathrm{ml}$ (Fig. $1 \mathrm{~A}$ and $1 \mathrm{C}$ ). The initial stimulatory action was observed during the first $10 \mathrm{~min}$ and thereafter the acid secretory rate declined gradually until reaching almost half of the basal secretory rate within $30 \mathrm{~min}$. The nonionic detergent, Triton $\mathrm{X}-100\left(1 \div 10^{-3}\right.$ $\mathrm{g} / \mathrm{ml}$ ) also stimulated gastric acid secretion to $468 \mathrm{~m} /, \mathrm{eq} \cdot \mathrm{H}^{+} / 4 \mathrm{~cm}^{2} / 10 \mathrm{~min}$ at the first $10 \mathrm{~min}$ period, and then depressed acid secretory rate $10220 \mathrm{~m} / \mathrm{eq} . \mathrm{H}^{+} / 4 \mathrm{~cm}^{2} / 10 \mathrm{~min}$ at the fourth 10 min period after the incubation. Fig. 1 also shows the effects of two agents on transmucosal P.D. In most of the preparations, conpound 48:80 and Triton X-100 showed a transient increase in transmucosal P.D. immediately after they were added. However, the effects on P.D. were not uniform in each experiment. As shown in Table 1, polymixin B 

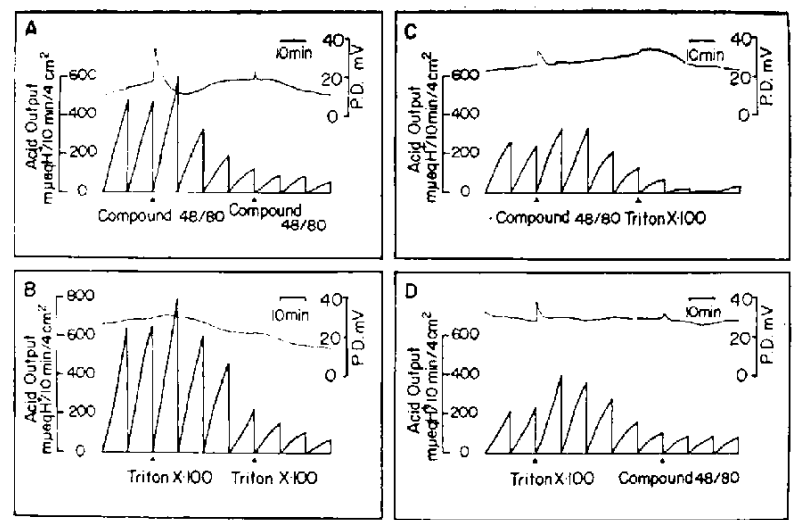

FIG. 1. Effect of histamine releasing agents on gastric acid secretion in isolated bullfrog gastric mucosa. Ordinate : the rate of acid output (mreq, $\mathrm{H}^{+} / 4$ $\mathrm{cm}^{2} / 10 \mathrm{~min}$ ). Compound 48/80:1 $\times 10^{-4} \mathrm{~g} / \mathrm{ml}$. Triton $\mathrm{X}-100: 1 \times 10^{-3}$ $\mathrm{g} \mathrm{ml}$. The upper trace in each column illustrates the change in transmucosal P.D. The base line indicates pH 6 .

and decylamine also showed similar effects on basal acid secretion in isolated frog gastric mucosa preparation.

The cross-inffuence of compound 48/80 and Triton X-100 on acid secretion was also examined. The gastric mucosae used in this experiment were pretreated with either compound $48 / 80\left(1 \times 10^{-4} \mathrm{~g} / \mathrm{ml}\right)$ or Triton $\mathrm{X}-100\left(1 \times 10^{-3} \mathrm{~g} / \mathrm{ml}\right)$ for $40 \mathrm{~min}$, and then each drug was added to the serosal solution with or without changing accomodation. As shown in Fig. 1, both compound 48,80 and Triton X-100 no longer showed the transient stimulatory action in the preparation preincubated with compound $48 / 80$ or Triton X-100.

Interaction of histamine relcasing agchts with histamine $H_{2}$-receptor antagonist

Burimamide was found to show a specific competitive antagonism to histamine $\mathrm{H}_{2}$ receptors without any significant interaction with histamine $\mathrm{H}_{1}$, acetylcholine-, and catecholamine beta-receptors (16). Thus, it is expected that the action of histamine releasing agents would be blocked by a histamine $\mathrm{H}_{2}$-receptor antagonist, if the stimulation by these drugs of acid secretion is due to endogenous histamine released from the gastric mucosa. It was confirmed that this preparation responded well to the three representative secretagogues, histamine, tetragastrin and bethanechol, that their actions were concentration-dependent and that the maximum acid secretory responses to each stimulant were nearly equal (Fig. 2). In this figure also, it can be seen that the secretagogue effect of histamine $\left(1 \times 10^{-5} \mathrm{~g} / \mathrm{ml}\right)$ was completely blocked by burimamide $\left(1 \times 10^{-4} \mathrm{~g} / \mathrm{ml}\right)$. In addition, it was found that the actions of an equipotent concentration of tetragastrin $\left(5 \times 10^{-7} \mathrm{~g} / \mathrm{ml}\right)$ and bethanechol $\left(1 \times 10^{-6} \mathrm{~g} / \mathrm{ml}\right)$ could be fully inhibited by burimamide even in a lower concentration than that required to depress the action of histamine. Fig. 3 and Table 1 indicate that pretreatment with burimamide in the lower concentration completely blocked the transient stimulatory actions of compound 48/80 and Triton X-100. The effects of three secretagogues 


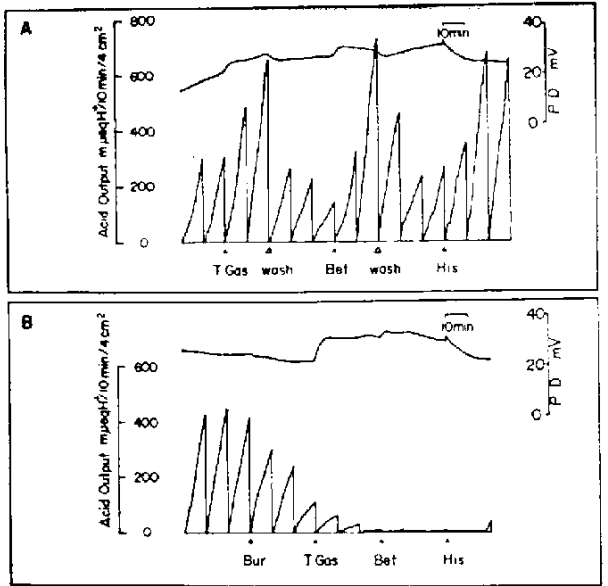

FIG. 2. Effect of secretagogues on gastric acid secretion and inhibition by burimamide in isolated bullfrog gastric mucosa. T-Gas. : tetragastrin $5 \times 10^{-7} \mathrm{~g} / \mathrm{ml}$. Bet. : bethanechol $1 \times 10^{-6} \mathrm{~g} / \mathrm{ml}$. His. : histamine $1 \times 10^{-5} \mathrm{~g} / \mathrm{ml}$. Bur. : burimanide $1 \times 10^{-4}$ $\mathrm{g}: \mathrm{ml}$. Otherabbreviations as in Fig. 1.
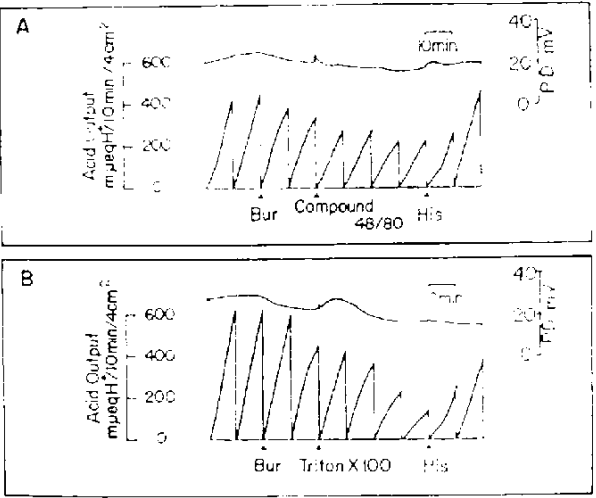

FIG. 3. Influence of burimamide on the stimulatory action of histamine relcasing agents in isolated bullfrog gastric mucosa. Bur. : burimamide $1 \times 10^{-5} \mathrm{~g} / \mathrm{ml}$. Compound 48,80: $1 \times 10^{-4} \mathrm{~g} / \mathrm{ml}$. Triton X-100: $1 \quad 10^{-3} \mathrm{~g} / \mathrm{ml}$. Other abbreviations as in Fig. 1.

TABLE 1. Effect of histamine releasing agents on gastric acid secretion in isolated bullfrog gastric mucosa

\begin{tabular}{|c|c|c|c|c|c|}
\hline & $\begin{array}{c}\text { Histamine relcasing } \\
\text { agents }\end{array}$ & $\mathrm{g} / \mathrm{ml}$ & No. & $\begin{array}{c}\text { Change in acid } \\
\text { outpul lirst } 10 \\
\text { min period }\end{array}$ & $\begin{array}{l}\text { (m/:cq. } \mathrm{H}^{+} / 4 \mathrm{~cm}^{2} / 10 \\
\text { min) fourth } 10 \mathrm{~min} \\
\text { period }\end{array}$ \\
\hline \multirow[t]{2}{*}{ i) } & compound $48: 80$ & $1 \times 10^{-4}$ & 10 & $\therefore 82 \cdots 10$ & $-78 !-8$ \\
\hline & polymixin $B$ & $5 \times 10^{-4}$ & 5 & $\therefore 78=15$ & $-118 \div 19$ \\
\hline \multirow[t]{2}{*}{ ii) } & Triton X-100 & $1 \times 10^{-3}$ & 10 & $84=13$ & $-164-20$ \\
\hline & decylamine & $1 \times 10^{-3}$ & 5 & $-93 \perp 19$ & $-180 \pm 24$ \\
\hline \multirow[t]{2}{*}{ iii) } & $\begin{array}{l}\text { compound } 48 / 80 \\
\text { pretreated with burimamide }\end{array}$ & & 10 & $-49=8$ & $-116 \pm 23$ \\
\hline & $\begin{array}{l}\text { Triton X-100 } \\
\text { pretreated with burimamide }\end{array}$ & & 10 & $-40=6$ & $-185 \pm 18$ \\
\hline
\end{tabular}

The mean basic acid output of 55 experiments was $384-21 \mathrm{~m}$ eq. $\mathrm{H}^{+} / 4 \mathrm{~cm}^{2} / 10 \mathrm{~min}$. Histamine releasing agents were added $20 \mathrm{~min}$ after the pretreatment with burimamide $\left(1 \times 10^{-5} \mathrm{~g} / \mathrm{ml}\right)$.

on transmucosal P.D. were not affected by the antagonist. From these results, it is suggested that stimulatory action by histamine liberators of acid secretion may be attributed to endogenous histamine.

\section{Interaction of histamine releasing agents with histamine, tetragastrin or bethanechol}

Histamine, tetragastrin and bethanechol stimulated acid secretion almost to the same degree in normal preparation in vitro. On the contrary, gastric mucosa pretreated with histamine releasing agents did not respond to tetragastrin and bethanechol. Fig. 4 shows 

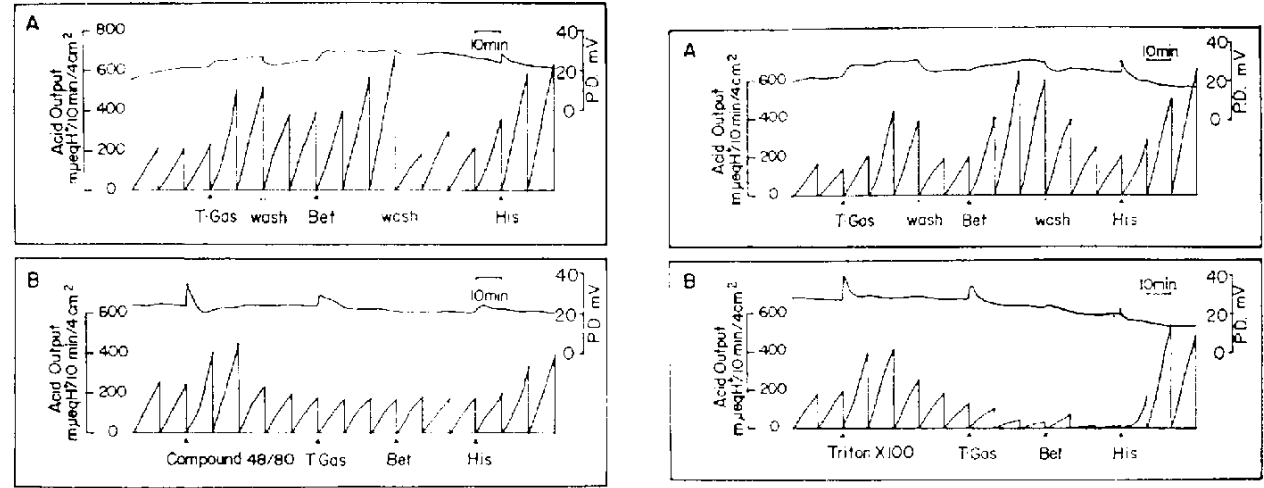

FIG. 4. Influence of compound 48:80 pretreat ment on the stimulatory action of three secretagogues in isolated bullfrog gastric

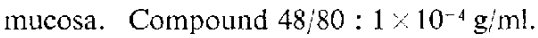
Other abbreviations as in Figs. 1, 2.

FIG. 5, Influence of Triton X-100 pretreatment on the stimulatory action of three secretagogues in isolated bullfrog gastric mucosa. Triton X-100: $1 \times 10^{-3} \mathrm{~g} / \mathrm{ml}$. Other abbreviations as in Figs. 1, 2 .

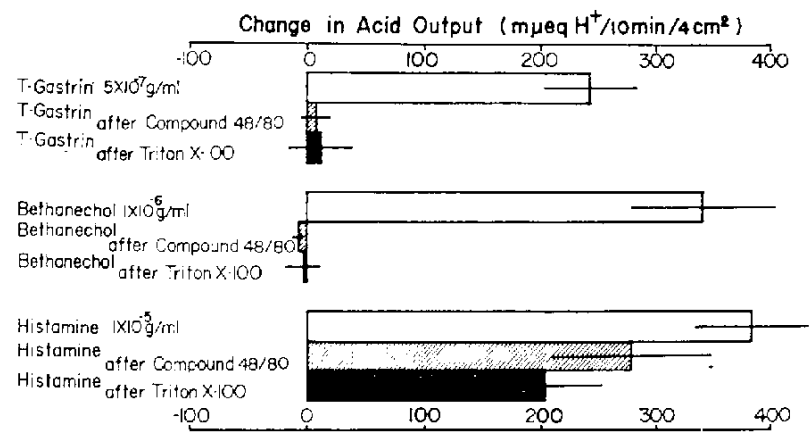

FIG. 6. Influence of pretreatment by histamine relcasing agents on the stimulatory action of three secretagogues in isolated bullfrog gastric mucosa. Each secretagogue was added 40 min after pretreatment with compound $48: 80\left(1 \times 10^{-4}\right.$ $\mathrm{g} / \mathrm{ml})$ or Triton $\mathrm{X}-100\left(1 \times 10^{-3} \mathrm{~g} / \mathrm{ml}\right)$. Each column shows the mean of $6 \mathrm{ex}-$ periments with S.E.M.

that three secretagogues stimulated acid production nearly to the maximum in normal tissue (upper trace), but the mucosal strips were not stimulated by tetragastrin and bethanechol after pretreatment with compound 48/80 (lower trace). It should be noticed that only histamine stimulated acid secretion in both normal and compound $48 / 80$ pretreated preparations. A similar experiment with Triton $X-100$ is presented in Fig. 5. The results of repeated trials with histamine liberators as pretreatments are summarized in Fig. 6 .It was found that after the pretreatment with compound $48 / 80$ or Triton X-100, the gastric mucosa became refractory to the stimulatory effect of tetragastrin and bethanechol, but it continued to respond to histamine, even though the response was much less than in a normal preparation. Pretreatment with either histamine liberator produced little effect on P.D. responding to each secretagogue. 
Effect of histamine releasing agents on gastric histamine content and histamine release in isolated gastric mucosa preparation

The isolated stomach was treated with compound $48 / 80\left(1 \times 10^{-4} \mathrm{~g} / \mathrm{ml}\right)$ or Triton X-100 $\left(1 \times 10^{-3} \mathrm{~g} / \mathrm{ml}\right)$. These concentrations were selected to obtain a clear increase in acid secretion. The gastric mucosa exposed to serosal Ringer solution served as the control. Thirty min later, the specimens (gastric mucosa and the serosal contents) were assayed to determine the amount of histamine. In eight experiments, the mean histamine content in gastric mucosa was $2.57 \doteq 0.15 \mu \mathrm{g} / \mathrm{g}$ tissue (Table 2). It was found that the gastric histamine content was reduced by compound $48 / 80$ and significantly decreased by Triton X-100. On the other hand, the amount of histamine liberated into the serosal side solution during 30 min was increased by compound $48 / 80$ and Triton X-100 from $95.9 \mathrm{ng} / 30 \mathrm{~min}$ to 102.5 and $124.0 \mathrm{ng} / 30 \mathrm{~min}$, respectively. From these results, it is suggested that the decrease of histamine content in gastric mucosa corresponded with the increase of histamine released into the serosal solution.

TABLE 2. Effect of histamine releasing agents on gastric histamine content and histamine relcase in isolated bullfrog gastric mucosa

\begin{tabular}{lccc}
\hline Treatment & No. & $\begin{array}{c}\text { Histamine content } \\
\text { in gastric mucosa } \\
r \mathrm{~g} / \mathrm{g} \text { tissue }\end{array}$ & $\begin{array}{c}\text { Histamine released } \\
\text { into serosal solution } \\
\mathrm{ng} / 4 \mathrm{~cm}^{2} 30 \mathrm{~min}\end{array}$ \\
\hline control & 8 & $2.57+0.15$ & $95.9 \pm 3.2$ \\
compound $48 / 801 \times 10^{-4} \mathrm{~g} / \mathrm{ml}$ & 8 & $2.17 \pm 0.16$ & $102.5 \pm 5.0$ \\
Triton $X-1001 \times 10^{-3} \mathrm{~g} / \mathrm{ml}$ & 8 & $1.71 \div 0.08^{* *}$ & $124.0 \div 7.9^{* *}$ \\
\hline
\end{tabular}

** $\mathrm{P}<0.01$ : significantly different from control (Student's $t$-test)

\section{DISCUSSION}

In the first series of the present experiments, it was revealed that all of the tested histamine liberators, including selective (compound 48/80 and polymixin $B$ ) and non-selective liberators (Triton X-100 and decylamine), showed a transient stimulatory effect followed by a gradual depression of basal acid secretion by isolated bulfrog gastric mucosa in vitro. The concentration of compound $48 / 80$ in our experiment was too high to be regarded as the dose which has selective action on mast cells. As to the stimulatory phase of the response, it was found that the gastric mucosa pretreated with a histamine liberator became refractory to a second application of the liberator. This observation was found to be applicable to cross interaction between compound 48/80 and Triton X-100. In addition, the stimulatory phase was completely inhibited by a histamine $\mathrm{H}_{2}$-receptor antagonist, burimamide. These results indicate that the stimulatory phase and the refractory phase after histamine releasing agents may be due to endogenous histamine. A related observation was made by Limlomwongse et al (9) who found that compound 48/80 depressed acid output in isolated gastric mucosa of the frog (Rana tigerina), and Triton X-100 showed a transient stimulation followed by a depression. These authors investigated the role of mast cells in the mucosa, but the relationship found between the tissue histamine level and 
secretory responses was not conclusive. Recently, Rangachari using isolated bullfrog gastric mucosa preparation (14), has directly demonstrated that gastric stimulants release histamine into the serosal solution. He assumed that the histamine released by stimulants in turn stimulated acid secretion. As shown in Table 2, compound 48/80 and Triton X-100 liberated histamine in this preparation. In addition, it was also observed that the histamine level in gastric mucosa was reduced by the application of compound 48/80 and Triton X-100. This observation was inconsistent with the result obtained by Limlomwongse et al (9) that the histamine content in Rana tigerina was not affected by compound 48/80. According to their report, Rana tigerina has a much higher gastric histamine content than Rana catesbeiana. Species differences may be the main cause of the discrepancy between the two observations. From our results, it seems likely that the secretagogue action of compound $48 / 80$ and Triton $\mathrm{X}-100$ is mediated by histamine in the bulifrog. Recent histochemical evidence has shown that histamine in gastric mucosa is concentrated in mast cells, enterochromaffin-like cells (6) and parietal cells (17), but knowledge of frog gastric mucosa is lacking. Thus, further histochemical investigations are necessary for discussion of the type of storage of the endogenous histamine in frog gastric mucosa.

Our second series of experiments was performed to elucidate the influence of the histamine liberators on secretagogue-stimulated acid secretion response. As shown in Figs. 4, 5 and 6 , gastric mucosa pretreated with a histamine liberator was found to become nonresponsive both to tetragastrin and bethanechol. On the other hand, the acid secretion induced by histamine was not affected by pretreatment with histamine liberators. Those results along with another series of our results, provide evidence that the action of the two secretagogues is closely related to endogenous histamine. Kahlson et al (18) found that the histamine forming capacity in rat stomach was significantly elevated by gastrin. Kasbekar et al (19) examined the relationship between pentagastrin and acetylcholine and endogenous histamine, and concluded that the secrctagogue action of both pentagastrin and acetylcholine was mediated by histamine. Many other reports also support the idea that histamine is a chemomediator candidate for the stimulatory effect of all gastric acid secretagogues. The present observations on the effect of histamine relcasing agents on isolated gastric mucosa are consistent with the ideas described above.

Acknowledgement: The present study was supported by Grant No. 077148 from the Ministry of Education, Japan.

\section{REFERENCES}

1) Gayin, G., McHenry, E.W. ANd Wilsox, M.J.: J. Physiol., 79, 234 (1933)

2) Code, C.F.: Fedn Proc. 24, 1311 (1965)

3) Kahlson, G. and Rosengren, E.: Physiol. Rev. 48, 155 (1968)

4) Schayer, R.W. and Ivy, A.C.: Am. J. Physiol. 193, 400 (1969)

5) Kahlson, G., Rosengren, E. And Svensson, S.E.: Pharmacology of Gastrointestinal Motility and Secretion, Edited by Holtov, P., p. 41, Pergamon Press, London (1973)

6) Hakanson, R.: Acta physiol. scand. Suppl. $\mathbf{3 4 0}$ (1970)

7) Feldobirg, W. and Talensivik, J.: J. Physiol. 120, 550 (1953)

8) Nishiyama, R.: Acta Med. Ohayama 10, 164 (1956) 
9) Limlomwongse, L., Thinthapandha, A. And Sobhon, P.: Proc. Soc. exp. Biol. Med. 142, $1281(1973)$

10) Davidson, W.D., Lemmi, C.A. and Thompson, J.C.: Gastric Secretion, Mechanisms and Control, Edited by Shnitka, T.K., Gilbert, J.A.L. And HArrison, R.C., p. 351, Pergamon Press, New York (1965)

11) Watanabe, K. and Goto, Y.: Europ. J. Pharmacol. 30, 133 (1975)

12) Goto, Y. and Watanabe, K.: Japan. J. Pharmacol. 25, 790 (1975)

13) Shore, P.A., Burkhalter, A. and Cohn, V.H. JR.: J. Pharmacol. exp. Ther. 127, 182 (1959)

14) Rangachari, P.K.: Nature 253, 53 (1975)

15) Rangachari, P.K.: Am. J. Physiol. 229, 627 (1975)

16) Black, J.W., Duncan, W.A.M., Durant, C.J., Ganflu.jn, C.R. and Parsons, E.M.: Nature 236, 385 (1972)

17) Товг, T.: Gastro-entero-pancreatic Endocrine System, Edited by Fumit, T., p. 90, Igaku Shoin Ltd., Tokyo (1973)

18) Kahlson, G., Rosengren, E., Svahn, E. and Thunberg, R.: J. Physiol. 174, 400 (1964)

19) Kasbekar, D.K., Ridley, H.A. and Forte, J.G.: Am. J. Physiol. 216, 961 (1969) 